\title{
The Effect of Facilities on Motivation and Its Impact on Accounting Understanding
}

\author{
Ahmad Rivai ${ }^{1}$, Sungguh Ponten Pranata ${ }^{2 *}$, Zakia Fadila ${ }^{3}$, Maya Syahlina ${ }^{4},{ }^{5}$ Berupilihen Br Ginting ${ }^{5}$ \\ ${ }^{1}$ Accounting, STIE Mahkota Tricom Unggul \\ ${ }^{2}$ Management, STIE Mahkota Tricom Unggul \\ 3,4,5 Accounting, Politeknik Unggul LP3M \\ ${ }^{*}$ Corresponding author: \\ Email: sungguh.ponten.aritonang@gmail.com
}

\begin{abstract}
.
The purpose of this study is to determine the role of facilities on accounting understanding through motivation as an intervening variable. The research method is quantitative. The population and samples came from active students as many as 112 respondents. The sampling technique used was quota sampling. The results showed that the facilities indirectly affected students' accounting understanding through motivation at STIE Mahkota Tricom Unggul. This means that motivation has a role in mediating facilities on accounting understanding.
\end{abstract}

Keywords: Facilities, Motivation, Understanding

\section{INTRODUCTION}

SITE Mahkota Tricom Unggul is one of the campuses that offer a D3 Accounting study program. The high interest of students in choosing the study program is proof that the SITE Mahkota Tricom Unggul campus has different values compared to other campuses. Efforts that have been made so far are by providing a tax certification program as a diploma companion. It aims to equip graduates that they are worthy and declared to have competence in the field of taxation. The core problem that has emerged so far is that there are still many students who do not pass the certification exam program from BNSP. Where the certificate is one of the mandatory requirements for students to attend court hearings. The following is a list of the percentage of students who took the certification exam for the last 3 years which shows that the increase in the number of students is not proportional to the percentage of students passing the BNSP certification exam. Although in the end students were given dispensation for the certification exam locally held by the Metro institution under the guidance of SITE Mahkota Tricom Unggul. This indicates that the level of accounting understanding possessed by students is not good enough to answer various questions in the certification exam. An understanding of the importance of taxes by a student can be seen from conceptual understanding such as the Tax Law and the ability to calculate taxes.

Knowledge and understanding of tax regulations is the process by which taxpayers know about taxation and apply that knowledge to pay taxes. Knowledge and understanding of tax regulations in question understand and understand general provisions and tax procedures (KUP) which includes how to submit a tax return (SPT), payment, place of payment, fines, and deadlines for payment or reporting of SPT [1]. Furthermore, understanding of taxation is obtained by internal factors (education, interests, experience, age) and external factors (economics, information, culture) [2].An employee who works generally has a variety of motivations. As a leader in a company, you should be able to understand how to motivate your subordinates [3]. Furthermore, a person's circumstances encourage the individual's desire to carry out certain activities to achieve company goals [4]. A leader often gives motivation to his subordinates. Where the motivation is divided into two, namely positive and negative motivation [5]. The motivation of a student to attend college well is highly expected, especially for lecturers. Based on the observations that the researchers got, students who have social studies education or accounting vocational school tend to be less enthusiastic about attending college. Only students with a science education background tend to be enthusiastic. This is what makes motivation will affect the behavior of students.Management continues to provide lecture facilities. 
Additional computer labs and infocus have been made to support lecturers in teaching.

However, this has not been seen to be able to significantly increase the percentage level of the number of students passing the BNSP certification. Furthermore, the use of learning facilities provides several benefits, namely: 1) The use of learning facilities can clarify messages and information so that they can facilitate and improve learning processes and outcomes. 2) Increase and excite children's attention so that it can lead to learning motivation, more direct interaction between students and their environment allows students to learn on their own according to their abilities. 3) Provide shared experiences to students about events in their environment, and allow direct interaction with teachers, the community, and their environment.The availability of lecture facilities that support the learning process is very necessary for both lecturers and students. With good facilities, a lecturer will easily provide material explanations and examples that are easy for students to understand [6]. Good learning facilities will be able to improve accounting understanding [7]. With supportive learning facilities coupled with high motivation, this will have an impact on increasing students' understanding of accounting [8].

\section{METHODS}

Path analysis was chosen in this study because it was considered appropriate to the research topic. Data analysis using SPSS. The population and sample in this study were active students of the accounting study program at SITE Mahkota Tricom Unggul for the 2019-2020 academic year, totaling 112 people. Where the sampling technique is quota sampling. Where the sample in this study amounted to 112 respondents. Furthermore, the data collection technique used a questionnaire that was distributed to the entire sample. The questionnaire measurement scale uses a Likert scale where: 1: Strongly Disagree, 2: Disagree, 3: Doubtful, 4 Agree, Strongly Agree. The variables in this study, namely facilities, are called independent or independent variables. Understanding referred to as the dependent variable is known as the dependent variable. Motivation is called the intervening variable.

\section{RESULT AND DISCUSSION}

\section{Research Instrument Test \\ Validity test}

Facility Variable

The results of the validity test of the customer loyalty variable are as follows:

Table 1. Facility Validity Test Results

\begin{tabular}{ccc}
\hline Statement & Corrected Item Total Correlation & Validitas \\
Item 1 & 0.605 & Valid \\
Item 2 & 0.416 & Valid \\
Item 3 & 0.702 & Valid \\
Item 4 & 0.648 & Valid \\
Item 5 & 0.745 & Valid \\
Item 6 & 0.803 & Valid \\
Item 7 & 0.724 & Valid \\
\hline
\end{tabular}

Source: SPSS Processing Results (2021)

Based on the table above, it is known that the question validity values for physical evidence are all valid because the total validity value is greater than 0.361 and can be used in subsequent calculations because all of them are declared valid.

Motivation Variable (Y1)

The results of the validity of the motivation variable are as follows:

Table 2. Motivation Validity Test Results (Y1)

\begin{tabular}{ccc}
\hline Statement & Corrected Item Total Correlation & Validitas \\
Item 1 & 0.681 & Valid \\
Item 2 & 0.487 & Valid \\
Item 3 & 0.515 & Valid \\
Item 4 & 0.634 & Valid \\
Item 5 & 0.713 & Valid \\
Item 6 & 0.738 & Valid \\
\hline
\end{tabular}




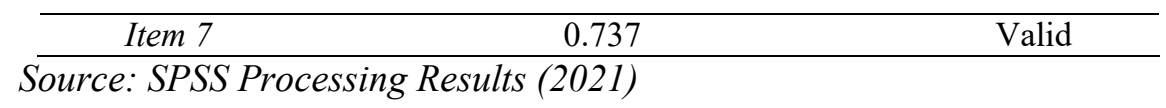

Based on the table above, the question validity values for motivation are all valid because the overall validity value is greater than 0.361 and can be used in subsequent calculations because all of them are declared valid.

\section{Accounting Understanding Variable (Y2)}

The results of the validity test of the accounting understanding variable are as follows:

Table 3. Results of Validity Test of Accounting Understanding (Y2)

\begin{tabular}{cccc}
\hline Statement & Corrected Item Total Correlation & $\mathbf{r}$ tabel & Validitas \\
Item 1 & 0.469 & 0,138 & Valid \\
Item 2 & 0.487 & 0,138 & Valid \\
Item 3 & 0.771 & 0,138 & Valid \\
Item 4 & 0.563 & 0,138 & Valid \\
Item 5 & 0.627 & 0,138 & Valid \\
Item 6 & 0.563 & 0,138 & Valid \\
Item 7 & 0.642 & 0,138 & Valid \\
\hline
\end{tabular}

Source: SPSS Processing Results (2021)

Based on the table above, it is known that the validity value of the questions for understanding accounting are all valid because the overall validity value is greater than 0.361 and can be used in subsequent calculations because all of them are declared valid.

\section{Reliability Test}

The results of the reliability test in this study are as follows:

Table 4. Instrument Reliability Test Results

\begin{tabular}{lc}
\hline \multicolumn{1}{c}{ Variabel } & Nilai Cronbach Alpha \\
Facility (X) & 0,878 \\
Motivation (Y1) & 0,868 \\
Accounting Understanding & 0,837 \\
(Y2) & \\
\hline
\end{tabular}

Source: SPSS Processing Results (2021)

Based on the table above, it is known that the Cronbach Alpha value for all variables is $>0.6$. So it can be stated that the five variables, namely competence, teaching style, facilities, motivation and understanding of accounting are reliable.

\section{The Effect of Facilities (X) on Motivation (Y1)}

It is known that the significance value for the facility variable (0.332) is greater than that of alpha $5 \%(0.05)$. Based on the results obtained, then reject $\mathrm{Ha}$ and accept. H0 for the facility variable. Thus, partially that the facility variable has no effect on college motivation at STIE Mahkota Tricom Unggul. The results of this study stated that the facilities had no effect on student motivation at STIE Mahkota Tricom Unggul. The results of this study are not in line with the results of research conducted by [9][10][11] which states that facilities affect college motivation. In research, the existing facilities at STIE Mahkota Tricom Unggul were not significantly able to increase student motivation to study. However, that does not mean that facilities are not important in increasing students' motivation to study, it's just that facilities are not the main element that makes students' motivation to study increase. Other elements are considered to be the most dominant in increasing the existing motivation.

\section{The Effect of Facilities (X) on Accounting Understanding (Y2)}

The results of data analysis show that the significance value of 0.238 is greater than that of alpha $5 \%$ (0.05). Based on the results obtained, then reject Ha and accept. H0 for the facility variable. Thus, partially that facilities have no effect on accounting understanding at STIE Mahkota Tricom Unggul. The results of the study stated that the facilities had no effect on students' accounting understanding at STIE Mahkota Tricom Unggul. These results do not support the results of research conducted by [12][13][8] which states that the facility can improve students' accounting understanding. The findings in this study imply that it is true that basically, facilities do not have a significant influence, but facilities are a supporting medium for activities during the lecture process. The most expected facilities are not just lecture rooms, infocus, 
blackboards, and so on. However, the facilities that have been expected so far, especially for students, are the opportunity to directly come to certain companies to see firsthand how the accounting cycle process occurs in the industrial world.

\section{The Effect of Motivation (Y1) on Accounting Understanding (Y2)}

It is known that the significance value for the motivation variable $(0.000)$ is smaller than that of alpha 5\% (0.05). Based on the results obtained, reject $\mathrm{H} 0$ and accept. Ha for the motivation variable. Thus, partially that motivation has a positive and significant effect on accounting understanding at STIE Mahkota Tricom Unggul. Based on the results of data analysis shows that motivation has a positive and significant effect on students' accounting understanding at STIE Mahkota Tricom Unggul. The results of this study are in line with previous research conducted by [14][15][16] which states that motivation has a significant effect on a student's accounting understanding. The implications of the findings in this study indicate that students with a high school education background majoring in science tend to have high motivation in attending lectures, especially material on accounting. Students with a high school education majoring in social studies and a vocational school majoring in accounting seemed less enthusiastic about participating. Some students considered that the material they had received, especially in school. So that the focus of some students is no longer towards understanding accounting but more towards the substance of how to allocate finances for a company or courses such as financial management or the theory of investment decision making.

\section{The Effect of Facilities (X) on Accounting Understanding (Y2) through Motivation (Y1)}

The direct effect of facilities on loyalty is by looking at the regression coefficient value of P6 of 0.060. The indirect effect of facilities on accounting understanding through motivation can be seen from the multiplication of the facility's regression coefficient on motivation with the value of the motivational regression coefficient on students' accounting understanding, namely $\mathrm{P} 3 \times \mathrm{P} 7=0.020 \times 0.488=0.009$. So it can be concluded that the value of the coefficient of indirect influence P3xP7 $<$ P6 $(0.009<0.060)$. This means that the motivation of the role in mediating facilities on students' accounting understanding at STIE Mahkota Tricom Unggul.The results of the study stated that the motivation of the role in mediating facilities on students' accounting understanding at STIE Mahkota Tricom Unggul. The results of this study are in line with the results of research conducted by [17][18][19] which states that motivation has a role in mediating facilities in improving accounting understanding. The implication of the findings in the study shows that if the facilities are not directly significant to the understanding of accounting, but with the mediation of motivation, the facilities have a role in increasing students' understanding of accounting.

\section{CONCLUSION}

Based on the results of the research and discussion above, the conclusions in this study are as follows:

1. Facilities do not directly affect student motivation at STIE Mahkota Tricom Unggul.

2. Facilities do not directly affect students' accounting understanding at STIE Mahkota Tricom Unggul

3. Indirectly, facilities affect students' accounting understanding through motivation at STIE Mahkota

Tricom Unggul. This means that motivation has a role in mediating facilities on accounting understanding.

The suggestions in this study are as follows:

1. Management should provide facilities, not only advice and educational infrastructure, but also student facilities to be able to make industrial visits to several partners.

2. Lecture motivation can be increased by providing stimulus to each student before carrying out learning activities. Lecturers are required to provide motivational words or videos that can inspire students to participate in the educational process while at STIE Mahkota Tricom Unggul.

\section{ACKNOWLEDGMENTS}

The researcher expresses his deepest gratitude specifically to the Directorate of Research and Service (DRPM) which has provided support in the form of funding for this research. Furthermore, the researcher appreciates all parties involved such as research members, chairpersons, lecturers, and students of SITE Mahkota Tricom Unggul who have helped the completion of this research by the time set. 


\section{REFERENCES}

[1] Siti Resmi, Perpajakan Teori dan Kasus, Buku 1 edisi 8. Jakarta: Salemba Empat, 2014.

[2] Notoatmodjo, Perpajakan. Jakarta: Salemba Empat, 2010.

[3] A. F. Nasib, Mengenal Dasar Manajemen. Jawa Tengah: CV. Pena Persada, 2020.

[4] T. Hani Handoko, Manajemen Personalia dan Sumber Daya Manusia. Yogyakarta: BPFE, 2012.

[5] Malayu Hasibuhan, Manajemen Sumber Daya Manusia, Edisi Revisi. Jakarta: Bumi Aksara, 2014.

[6] Wardani, "Pengaruh Lingkungan Belajar , Fasilitas , dan Metode Mengajar Guru melalui Motivasi terhadap Hasil Belajar The Effect of Enviromental Education In School, Education Facilities, The Teacher Learning Method Through Learning,” J. Educ. Hum. Soc. Sci., vol. 3, no. 3, pp. 1307-1315, 2021.

[7] D. S. R. Setiyani, "Pengaruh Kompetensi Pedagogik Guru Dan Fasilitas Belajar Terhadap Prestasi Belajar Melalui Motivasi Belajar,” Econ. Educ. Anal. J., vol. 7, no. 2, pp. 390-399, 2018.

[8] D. K. Suharno, "Analisis Pengaruh Kecerdasan Emosional, Spiritual, Sosial dan Fasilitas Pembelajaran Terhadap Tingkat Pemahaman Akuntansi,” Res. Fair Unisri 2019, vol. 4, no. 1, pp. 291-300, 2020.

[9] I. K. S. Arsana, "Pengaruh Keterampilan Mengajar Guru Dan Fasilitas Belajar Terhadap Motivasi Belajar Siswa,” Sos. Horiz. J. Pendidik. Sos., vol. 6, no. 2, pp. 269-282, 2019.

[10] B. E. Damanik, "Pengaruh Fasilitas Dan Lingkungan Belajar Terhadap Motivasi Belajar," Publ. Pendidik., vol. 9, no. 1, pp. 46-52, 2019.

[11] R. H. Tanjung, "Pengaruh Kompetensi, Motivasi Dan Kepuasan Kerja Terhadap Kinerja Pegawai," Maneggio J. Ilm. Magister Manaj., vol. 2, no. 1, pp. 1-15, 2019.

[12] K. M. E. Nurmalasari, "Pengaruh Kompetensi Dosen Dan Fasilitas Belajar Terhadap Pemahaman Matakuliah Pelaporan Dan Laporan Keuangan Dengan Internal Locus Of Control Sebagai Variabel Moderasi ( Studi Kasus Mahasiswa Prodi Akuntansi Politeknik Unggul LP3M Medan)," in Prosiding Konferensi Nasional Ke- 8, 2018, pp. $1-12$.

[13] F. B. A. N. R. D. Kristianto, "Pengaruh Kecerdasan Emosional, Kecerdasan Intelktual, Perilaku Belajar, Kompetensi Dosen Dan Fasilitas Pembelajaran Terhadap Tingkat Pemahaman Akuntansi," J. Akunt. dan Sist. Teknol. Inf., vol. 14, no. 2, pp. 351-360, 2018.

[14] V. S. A J. Akunt. dan Sist. Teknol.. A. Hariri, "Pengaruh Motivasi, Self Efficacy, Dan Pemahaman Pada Peraturan Menteri Keuangan No. 111/Pmk.03/2014 Terhadap Minat Berkarir Mahasiswa Akuntansi Sebagai Konsultan Pajak," E-JRA, vol. 09, no. 01, pp. 69-84, 2020.

[15] D. H. A. Feranika, "Pengaruh Pengendalian Diri , Motivasi , Perilaku dan Minat Belajar terhadap Tingkat Pemahaman Akuntansi (Studi Empiris Pada Mahasiswa IAI Nusantara Batanghari dan Universitas Dinamika Bangsa Jambi)," BIEJ Bus. Innov. Entrep. Journal, vol. 2, no. 4, pp. 232-241, 2020.

[16] H. Fajarsari, "Pengaruh Motivasi dan Persepsi Terhadap Minat Mahasiswa Mengikuti Pendidikan Profesi Akuntansi ( PPAK ) di Kota Semarang,” Pamator, vol. 13, no. 1, pp. 30-43, 2020.

[17] I. J. A. L. O. Muharram, "Pengaruh Gaya Mengajar Terhadap Motivasi Dan Prestasi Belajar Ekonomi Siswa SMA Negeri Berbasis K-13 Di Kabupaten Konawe Selatan,” J. Wahana Kaji. Pendidik. IPS, vol. 1, no. 1, pp. 56-67, 2017.

[18] A. Reski, "Pengaruh Fasilitas Belajar Terhadap Motivasi Dan Hasil Belajar Fisika Mahasiswa," Musamus J. Sci. Educ., vol. 1, no. 1, pp. 1-8, 2018.

[19] A. Listiana, "Pengaruh Pemahaman Perpajakan, Intensitas Pemberian Tugas dan Gaya Belajar Terhadap Hasil Belajar Akuntansi Perpajakan Dengan Motivasi Belajar Sebagai Variabel Moderating Pada Mahasiswa Pendidikan Akuntansi Fakultas Ekonomi Universitas Negeri Surabaya,” J. Pendidik. Akunt., vol. 07, no. 03, pp. 294-300, 2019. 